\title{
Kluyveromyces marxianus flocculence and growth at high temperature is dependent on the presence of the protein p37
}

\author{
R. Falcão Moreira, ${ }^{1,3}$ P. A. Fernandes ${ }^{1,2}$ and P. Moradas-Ferreira, ${ }^{1,4}$ \\ Author for correspondence: P. Moradas-Ferreira. Tel: +3512 6074900. Fax: +35126099157. \\ e-mail : pmferrei@ncc.up.pt
}

\footnotetext{
${ }^{1}$ Instituto de Biologia Molecular e Celular (IBMC), Rua do Campo Alegre, 823, 4150 Porto, Portugal

2 Escola Superior de Tecnologia e Gestão do Instituto Politécnico de Viana do Castelo, Portugal

3 Instituto Superior de Ciências da Saúde 3 , Paredes, Portugal

4 Instituto de Ciências Biomédicas Abel Salazar, Universidade do Porto, Portugal
}

\begin{abstract}
A Kluyveromyces marxianus mutant deficient in p37, a glyceraldehyde-3phosphate dehydrogenase (GAPDH)-like protein, was obtained and characterized with respect to flocculation behaviour, resistance to temperatures above the optimum for growth, morphology, growth, calcofluor white sensitivity and GAPDH activity. In YPD media, the mutant cells were unable to flocculate and were thermosensitive. However, this thermosensitivity could be overcome by the presence of calcium. Calcofluor white was toxic to the mutant, indicating that the mutation affects cell wall structure. The contribution of p37 to total GAPDH activity was $25 \%$ when cells were using glucose as carbon source and $50 \%$ when cells were growing in $3 \%$ ethanol. These results indicate that p37 is likely to be involved in thermotolerance and flocculation, which can be related to its contribution to cell wall integrity.
\end{abstract}

Keywords: thermotolerance, flocculation, Kluyveromyces marxianus, cell wall proteins

\section{INTRODUCTION}

Yeast flocculation results from the aggregation of hundreds or thousands of cells due to interactions between components of the cell wall surface. The nature of these cell interactions has been elucidated by several approaches, for example protein synthesis inhibition by cycloheximide (Nishihara et al., 1976) and proteinase K digestion (Nishihara et al., 1977), indicating the involvement of proteins (Moradas-Ferreira et al., 1994). In 1982, Miki et al. proposed a tentative model in which flocculation results from interactions between lectins and carbohydrates on the surface of the cell walls. More data have since become available that support this model (Stratford \& Carter, 1993).

Kluyveromyces marxianus flocculation is concomitant with the accumulation of a protein (p37) in the wall of flocculent cells. Indeed, the p37 concentration in the cell wall increases to $11 \%$ of the total wall proteins released by SDS, suggesting that it is involved in the interaction between cells leading to flocculation (Fernandes $e t$ al., 1992, 1993). Although it is well established that cell wall proteins are responsible for flocculation and different putative flocculins have been identified in Saccharo-

Abbreviation: GAPDH, glyceraldehyde-3-phosphate dehydrogenase. myces cerevisiae (Stewart et al., 1976; Holmberg, 1978) and Hansenula anomala (Saito et al., 1990), definitive proof for such a role has only been presented for proteins encoded by the Flo genes in S. cerevisiae (Stewart \& Russell, 1977; Russell et al., 1980; Vezinhet et al., 1991; Teunissen, et al., 1993). Brewer's yeast flocculence has been related to an increase in cell surface hydrophobicity, apparently induced by growth limitation, and correlated with the presence of large numbers of bundles of long fimbriae-like structures on the cell surface (Straver et al., 1993).

Purification and characterization of $K$. marxianus $\mathrm{p} 37$ revealed a high identity to cytosolic glyceraldehyde-3phosphate dehydrogenase (GAPDH). Subsequently, the gene encoding p37, GAP1, was cloned, sequenced and identified as a member of the GAPDH multigenic family of $K$. marxianus, which consists of three genes: GAP1 (encoding p37), GAP2 and GAP3. The coding region of these genes has high homology: the identity between GAP2 and GAP3 is almost $99 \cdot 6 \%$, and between these two genes and GAP1 is $86 \%$ (Fernandes et al., 1995). In contrast, the homology between the known flanking regions of GAP1 and the flanking regions of GAP2 and $G A P 3$ is lower $(55 \%)$. There is differential expression of the members of the GAPDH family: in the presence of glucose, GAP1 and GAP2 mRNA synthesis is observed but no GAP3 transcripts can be detected; using a non- 


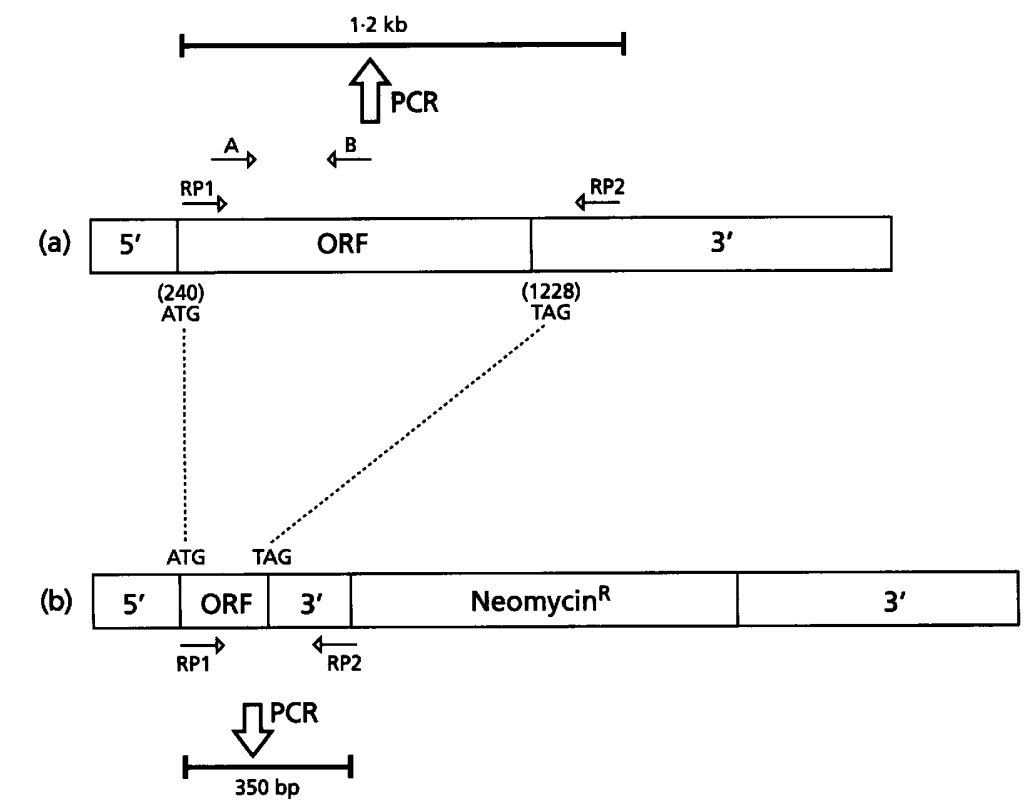

Fig. 1. GAP1 disruption by excision of part of the coding region and introduction of the neomycin resistance gene. (a) PCR amplification of the GAP1 coding region using RP primers results in PCR products of $1.2 \mathrm{~kb}$. The positions of primers $A$ and $B$ are shown. (b) PCR amplification of the disrupted GAP1 gene using RP primers results in PCR products of $350 \mathrm{bp}$. 3', 3' flanking region; 5', 5' flanking region.

fermentable carbon source such as ethanol, the transcription of the GAP2 gene is strongly reduced, in contrast to the transcription activation of GAP1 (Fernandes et al., 1995).

Since p37 is present on the cell surface, a signal peptide was expected to be found in its amino-terminal end. However, gene sequence analysis did not show any sequence coding for a hydrophobic peptide that could be identified as a signal for protein translocation to the endoplasmatic reticulum. Therefore, this translocation could not be mediated by the SRP (signal recognition particle); thus it must utilize another mechanism, as also reported for 3-phosphoglycerate kinase, another glycolytic enzyme (Alloush et al., 1997).

In the present work, aimed at evaluating the role of $\mathrm{p} 37$ in the cell wall and its correlation with flocculation, $a K$. marxianus mutant deficient in p37 was obtained by GAP1 disruption. The mutant cells were no longer able to flocculate and became temperature-sensitive. This could be related to changes in cell wall stucture, as suggested by the sensitivity of the mutants to calcofluor white.

\section{METHODS}

Cell growth conditions. K. marxianus ATCC 10022 cells were grown in YPD ( $2 \%$ glucose, $2 \%$ Bactopeptone and $1 \%$ yeast extract) or YP supplemented with ethanol as a carbon source ( $2 \%$ Bactopeptone, $1 \%$ yeast extract and $3 \%$ ethanol) at $26^{\circ} \mathrm{C}$ or $40^{\circ} \mathrm{C}$.

GAP1 disruption. This was performed using the 'one-step gene disruption method' (Rothstein, 1983). Part of the coding region between base 353 and base 1205 was excised by digestion with Sall. The neomycin resistance gene was introduced in the $3^{\prime}$ flanking region of the disrupted gene (Fig. 1). A PCR amplification product of this fragment, including the $240 \mathrm{bp} 5^{\prime}$ flanking region and $800 \mathrm{bp}$ of $3^{\prime}$ flanking region, was used to transform K. marxianus ATCC 10022 cells.

Yeast transformation. $K$. marxianus cells were transformed by the spheroplast transformation method (Ausubel et al., 1987).

PCR. This was performed using $500 \mathrm{ng}$ genomic DNA and PCR primers RP1 (5' AAAGGATCCAGATGGTTTCTATTGCTAT $3^{\prime}$ ) and RP2 (5' AACGGATCCCTAAGACCTGAAAGACATT $\left.3^{\prime}\right)$. A final volume of $50 \mu \mathrm{l}$ was used and the conditions were as follows: $1 \mathrm{mM}$ of each primer, $200 \mathrm{mM}$ Tris/ $\mathrm{HCl}$ (pH 8.4) $500 \mathrm{mM} \mathrm{KCl}, 7 \mathrm{mM} \mathrm{MgCl}, 200 \mathrm{mM}$ dNTPs. One unit of Taq polymerase (Gibco BRL) was added after an initial denaturation step of $10 \mathrm{~min}$ at $94^{\circ} \mathrm{C}$, followed by 30 cycles of $94^{\circ} \mathrm{C}$ for $40 \mathrm{~s}, 60^{\circ} \mathrm{C}$ for $1 \mathrm{~min}$ and $72^{\circ} \mathrm{C}$ for $1 \mathrm{~min}$. The PCR products were analysed on a $0.8 \%$ agarose gel.

Southern blot and hybridization. Aliquots $(20 \mu \mathrm{l})$ of $K$. marxianus ATCC 10022 wild-type and gap1 mutant genomic DNA were digested with HindIII. The digested DNA was separated in a $0.8 \%$ agarose gel and transferred onto Hybond$\mathrm{N}$ nylon membrane (Amersham) under alkaline conditions (Sambrook et al., 1989). The DNA was covalently bound to the membrane by UV irradiation and subsequently pre-hybridized for $1 \mathrm{~h}$ at $65^{\circ} \mathrm{C}$ with $6 \times$ SSC, $5 \times$ Denhardt's solution, $0.5 \%$ SDS and $20 \mathrm{mg}$ herring sperm DNA ml $\mathrm{m}^{-1}$. The blot was hybridized in the same solution at $65^{\circ} \mathrm{C}$ for $16 \mathrm{~h}$ using as probe the ${ }^{32} \mathrm{P}$-labelled PCR fragment obtained from the amplification of the initial part $(350 \mathrm{bp})$ of the coding region of GAP1 with primers A $\left(5^{\prime}\right.$ ATTCGCTCATTCAACTGGTTTCGG $\left.3^{\prime}\right)$ and B ( $5^{\prime}$ AGGCAGTCAG ATGATGCTTTTATG $3^{\prime}$ ) (the positions of primers A and B are shown in Fig. 1), and using as template $25 \mathrm{ng}$ of the plasmid pGAPKm1 (containing the coding region and part of the flanking regions of GAP1).

Cell growth. Cells were inoculated into YPD or YPD supplemented with $\mathrm{CaCl}_{2}$ in an Erlenmeyer flask with five times the capacity of the volume of cell culture used. The cell cultures were incubated with shaking at $26^{\circ} \mathrm{C}$ or $40^{\circ} \mathrm{C}$. The 
optical density at $600 \mathrm{~nm}$ was determined each hour to evaluate cell growth.

Quantification of biomass. Aliquots $(50 \mathrm{ml})$ of cell culture were filtered under vacuum using a pre-weighed filter (ME 25/41 ST membrane filter, Schleicher \& Schuell). The cells were washed twice with sterile water and the filter was dried at $80^{\circ} \mathrm{C}$ for $24 \mathrm{~h}$. The filter was cooled in a dessicator and weighed to determine the amount of biomass present, expressed in $\mathrm{g}^{-1}$.

Quantification of glucose and ethanol in cell cultures. Samples $(2 \mathrm{ml})$ of culture were taken and centrifuged at $16000 \mathrm{~g}$ for $2 \mathrm{~min}$. The supernatants were stored at $-20^{\circ} \mathrm{C}$ until use. Ethanol was quantified using the ethanol UV test kit from Boehringer Mannheim. Glucose was quantified by the glucose oxidase/peroxidase method: $2.5 \mathrm{ml}$ TGO reagent $\left[0.5 \mathrm{M}\right.$ Tris $/ \mathrm{HCl}(\mathrm{pH} 7), 20 \mathrm{U}$ glucose oxidase $\mathrm{ml}^{-\mathbf{1}}$, $0.38 \mathrm{U}$ peroxidase $\mathrm{ml}^{-1}, 0.05 \mathrm{mg}$ o-dianisidine hydrochloride $\mathrm{ml}^{-1}, 1 \%$ Triton X-100] was added to $0.5 \mathrm{ml}$ of sample, the mixture was incubated for $20 \mathrm{~min}$ at $37^{\circ} \mathrm{C}$ and the absorbance at $420 \mathrm{~nm}$ was determined. Glucose was estimated by reference to a standard curve prepared with known amounts of glucose.

Calcofluor white sensitivity tests. These were performed according to the method described by Ram et al. (1994), with the following modifications: cells were incubated in $5 \mathrm{ml}$ YPD medium and incubated at $26^{\circ} \mathrm{C}$ until an $\mathrm{OD}_{640}$ of 8 was reached. Dilutions of $10,100,1000$ and 10000 times were prepared and $5 \mu$ l of each spotted on a YPD plate containing $50 \mu \mathrm{g}$ calcofluor white $\mathrm{ml}^{-1}$. The plates were incubated at $26^{\circ} \mathrm{C}$ and growth was evaluated after $2 \mathrm{~d}$ incubation (F. M. Klis, personal communication)

Enzyme assays. These were performed using the method described by Holland \& Westhead (1973).

\section{RESULTS}

\section{Disruption of the GAP1 gene}

To determine whether $K$. marxianus flocculation is dependent on the presence of p37, a gap1 mutant was produced by homologous recombination (Rothstein, 1983). This was performed by the introduction into $K$. marxianus ATCC 10022 of a DNA fragment of $3448 \mathrm{bp}$, obtained by PCR amplification of the disrupted gene. Two hundred and forty base pairs of GAP1 $5^{\prime}$ flanking region and $800 \mathrm{bp}$ of its $3^{\prime}$ flanking region were included in the PCR product used to transform the $K$. marxianus cells. This approach guaranteed that the homologous recombination could only occur between the flanking regions, aiming the specificity in the targeting of the mutation to GAP1, since the flanking regions, in contrast to the coding regions, are not homologous between the different members of the GAPDH gene family of $K$. marxianus.

\section{Analysis of genomic DNA}

To confirm the mutation of the GAP1 gene in the yeast genome, genomic DNA was prepared from either $K$. marxianus wild-type or transformed cells and screened by PCR and Southern blotting.

PCR. When the PCR products from the gap1 mutant obtained using primers (RP1 and RP2) designed for



Fig. 2. $P C R$ products obtained using RP primers designed for the amplification of the GAP1 coding region. Lanes: 1, gap1 mutant; 2 , wild-type; 3 , HindIII-digested $\lambda$ DNA size markers.

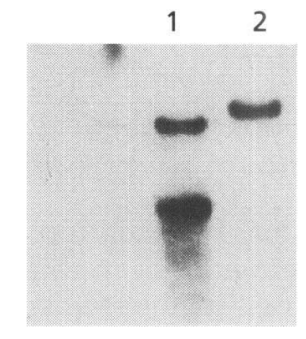

Fig. 3. Southern analysis of genomic DNA for the identification of the coding region of the three GAPDH genes of $K$. marxianus. Lanes: 1, wild-type; 2 gap 1 mutant.

amplification of part of the GAP1 coding region were separated on an agarose gel $(0 \cdot 8 \%)$, a DNA fragment of the expected size, $350 \mathrm{bp}$, was revealed, whilst the PCR product from the wild-type was $1 \cdot 2 \mathrm{~kb}$ (Figs 1,2 ).

Southern blotting. K. marxianus genomic DNA from wild-type and gap1 mutant cells was digested with $H$ indIII and hybridized with a ${ }^{32} \mathrm{P}$-labelled probe specific for the coding region of the three $K$. marxianus GAPDH family genes. As reported previously (Fernandes et al., 1995), a DNA fragment of $8.0 \mathrm{~kb}$ due to the presence of GAP2 and GAP3 and one band of $4.0 \mathrm{~kb}$ due to the presence of GAP1 should be obtained for wild-type cells. In fact, the two expected fragments were observed for wild-type $K$. marxianus, but only the $8.0 \mathrm{~kb}$ fragment was obtained for the mutant cells, indicating the absence of the intact GAP1 gene (Fig. 3).

\section{Characterization of the mutant}

With the aim of evaluating the effects of GAP1 disruption in $K$. marxianus, the mutant cells were characterized with respect to morphology, flocculation behaviour, growth, biomass, metabolism, calcofluor white sensitivity and GAPDH activity.

Morphology. Morphological analysis of the gap1 mutant by light microscopy showed that the (gap1) mutant cells 

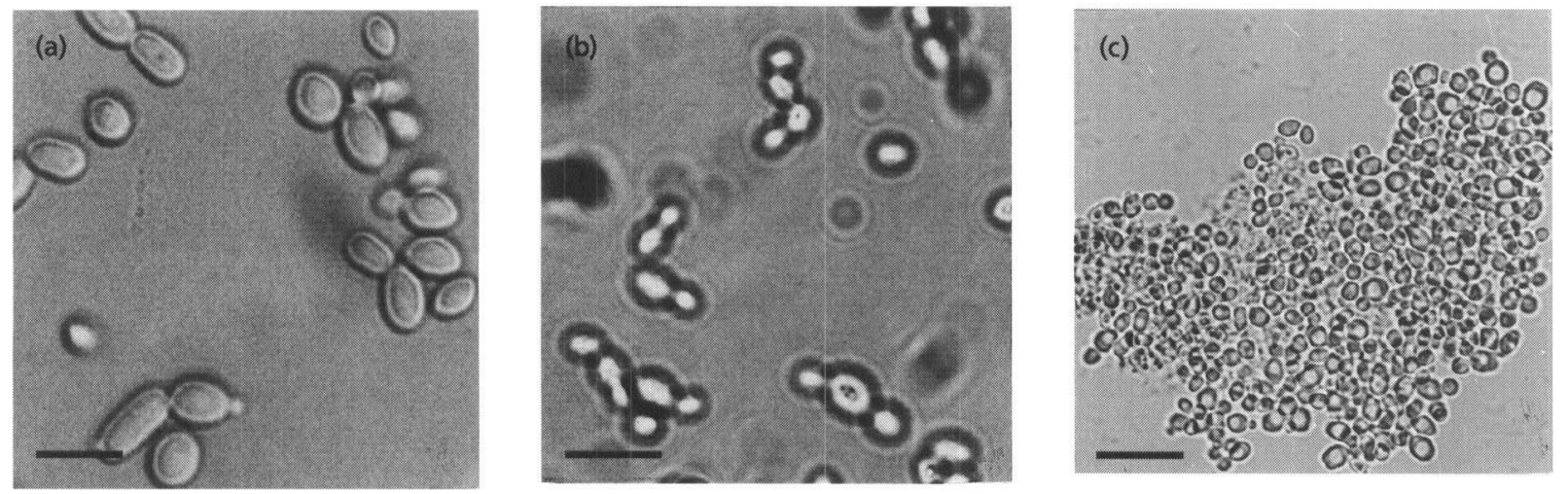

Fig. 4. (a) $\mathrm{K}$. marxianus wild-type cells grown in YPD at $26^{\circ} \mathrm{C}$. Bar, $6 \mu \mathrm{m}$. (b) gap1 mutant cells grown in YPD at $26^{\circ} \mathrm{C}$. Bar, $6 \mu \mathrm{m}$. (c) Flocculated $K$. marxianus wild-type cells grown in YPD medium containing $200 \mathrm{mM} \mathrm{CaCl}_{2}$ at $40{ }^{\circ} \mathrm{C}$. $\mathrm{Bar}$, $15 \mu \mathrm{m}$.

were smaller and looked spherical, in contrast to the elongated appearance of wild-type cells (Fig. 4a, b).

Flocculation behaviour. Flocculation tests revealed that the mutant cells were no longer able to flocculate when growing at $40^{\circ} \mathrm{C}$ in the presence of calcium as described for wild-type cells (Fernandes et al., 1993) (Fig. 4c).

Cell growth. This was evaluated at different temperatures, with carbon sources and in the presence of $\mathrm{CaCl}_{2}$. The results indicated that in YPD and at $26^{\circ} \mathrm{C}$, growth of the mutant cells was different from that of wild-type K. marxianus. The gap1 mutant had a much longer lag phase, followed by an exponential phase that led to a considerably higher final $\mathrm{OD}_{600}$ (Fig. 5a). When ethanol was used as the carbon source, the growth curve of the mutant differed from that of the wild-type, again leading to a higher $\mathrm{OD}_{600}$ (Fig. $5 \mathrm{~b}$ ). With regard to the effect of temperature on growth, it was verified that mutant cells were sensitive to an increase in temperature. Indeed, incubation of mutant cells at $40^{\circ} \mathrm{C}$ caused death, in contrast to wild-type cells, which were not affected (Fig. $5 \mathrm{c})$. If calcium ( $200 \mathrm{mM}$ ) was added to the culture medium of mutant cells, growth was rescued, although with a lower yield (Fig. 5c). It was verified that the mutant growth rate at $40^{\circ} \mathrm{C}$ was dependent on the calcium concentration; at increasing calcium concentrations $(50,100$ and $150 \mathrm{mM})$ growth increased proportionally (data not shown).

Biomass, glucose uptake and ethanol production. The results obtained concerning biomass showed that the dry weight values of the gap1 mutant cells were lower (about $15 \%$ less) than those of wild-type cells at equivalent $\mathrm{OD}_{600}$ values. Glucose uptake and ethanol production of mutant and wild-type $K$. marxianus cells were also different; in fact, the rate of glucose consumption was relatively higher in the gap1 mutant, and ethanol was produced in greater amounts (Fig. 6a, b). The ratio between the amount of biomass produced and quantity of substrate consumed was calculated for both mutant and wild-type cells. A lower value (about $0 \cdot 14$ ) was obtained for the gap1 mutant, compared to that (about $0 \cdot 20$ ) obtained for the wild-type cells.

Calcofluor white sensitivity. Calcofluor white is a negatively charged fluorescent dye that is used to detect cell wall mutants because it interferes with cell wall assembly. Cells with a weakened cell wall might not be able to withstand the additional disturbance of the cell wall caused by such a drug, resulting in lethality at concentrations that are not lethal to wild-type cells (Ram et al., 1994). Fig. 7 shows the effect of calcofluor white on gap1 mutant cells (Fig. $7 \mathrm{~b}$ ii) compared to its effects on wild-type K. marxianus cells (Fig. 7a ii).

Contribution to total GAPDH activity. The contribution of the GAP1 gene encoding $\mathrm{p} 37$ to total GAPDH activity was about $25 \%$ when cells were using glucose as carbon source and $50 \%$ in $3 \%$ ethanol (Table 1 ).

\section{DISCUSSION}

In previous studies on the flocculation of $K$. marxianus it was revealed that this yeast accumulates a small glycoprotein with an apparent molecular mass of $37 \mathrm{kDa}$ - p37 - concomitant with the ability to flocculate (Fernandes et al., 1993). This protein is encoded by a member of a GAPDH family named GAP1 which has high homology with the other two members of the family. However, in contrast to the other GAPDH genes, GAP1 expression was increased when ethanol was used as a carbon source. With the aim of elucidating the role of the p37 in flocculation behaviour, a gap1 mutant was obtained and characterized.

To this end, disruption of the GAP1 gene was achieved by removing a large portion of the coding region and inserting the neomycin resistance gene, a strategy that made use of the differences in the sequence of the flanking regions between GAP1, GAP2 and GAP3. The disruption of GAP1 was verified both by analysis of the 

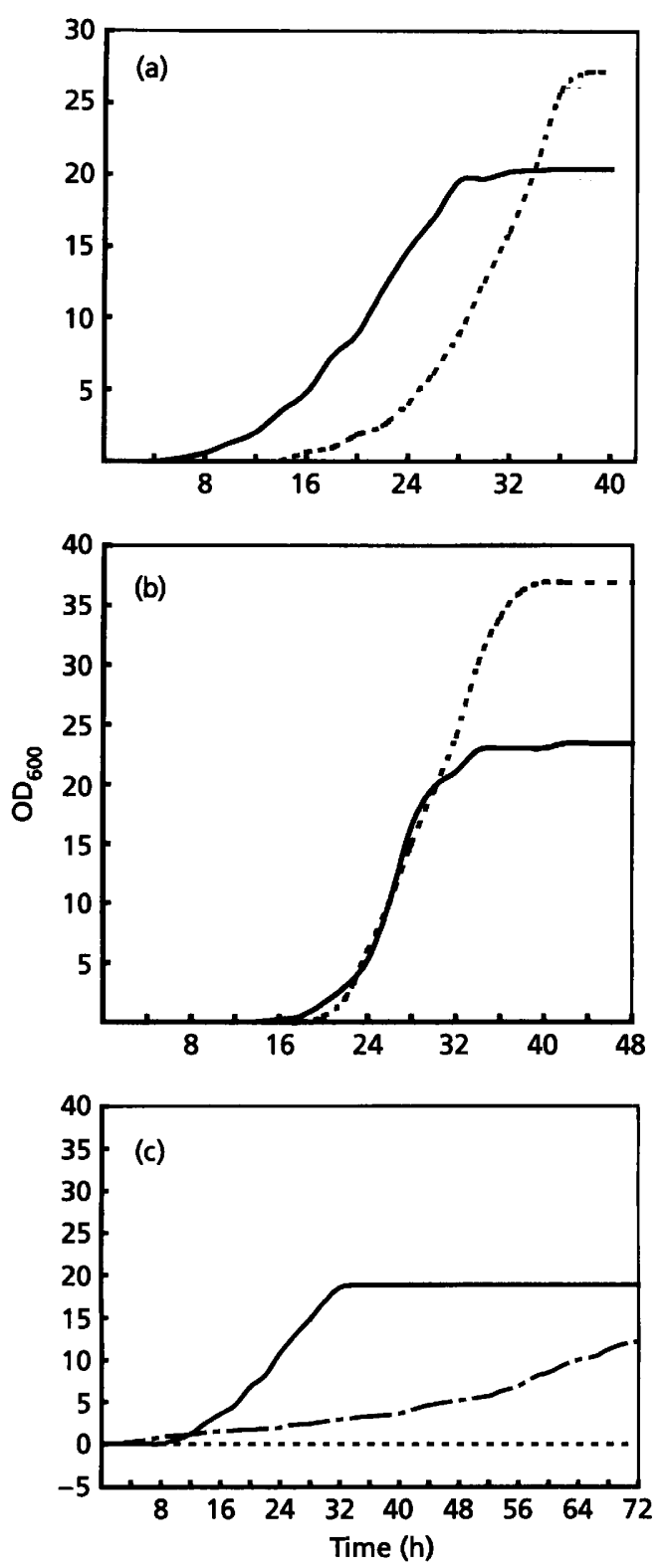

Fig. 5. (a) Growth of $K$. marxianus wild-type $(-)$ and gap1 mutant (--) cells in YPD medium at $26^{\circ} \mathrm{C}$. (b) Growth of $K$. marxianus wild-type $(-)$ and gap 1 mutant $(--)$ cells in YP medium supplemented with ethanol $(3 \%)$ at $26^{\circ} \mathrm{C}$. (c) Growth of wild-type $K$. marxianus cells in YPD medium at $40^{\circ} \mathrm{C}(-)$, and gap1 mutant cells in YPD medium $(--)$ and YPD supplemented with $200 \mathrm{mM} \mathrm{CaCl}_{2}(---)$ at $40^{\circ} \mathrm{C}$.

DNA fragments obtained by PCR using specific primers (Fig. 2) and by Southern analysis (Fig. 3), and both assays led to the conclusion that the mutation of GAP1 had been successful.

The mutant cells exhibited a different morphology (Fig. $4 a, b)$ when compared with the wild-type: they were smaller in size and they had a spherical instead of a more elongated shape. This altered morphology can be a natural consequence of genetic manipulation of the
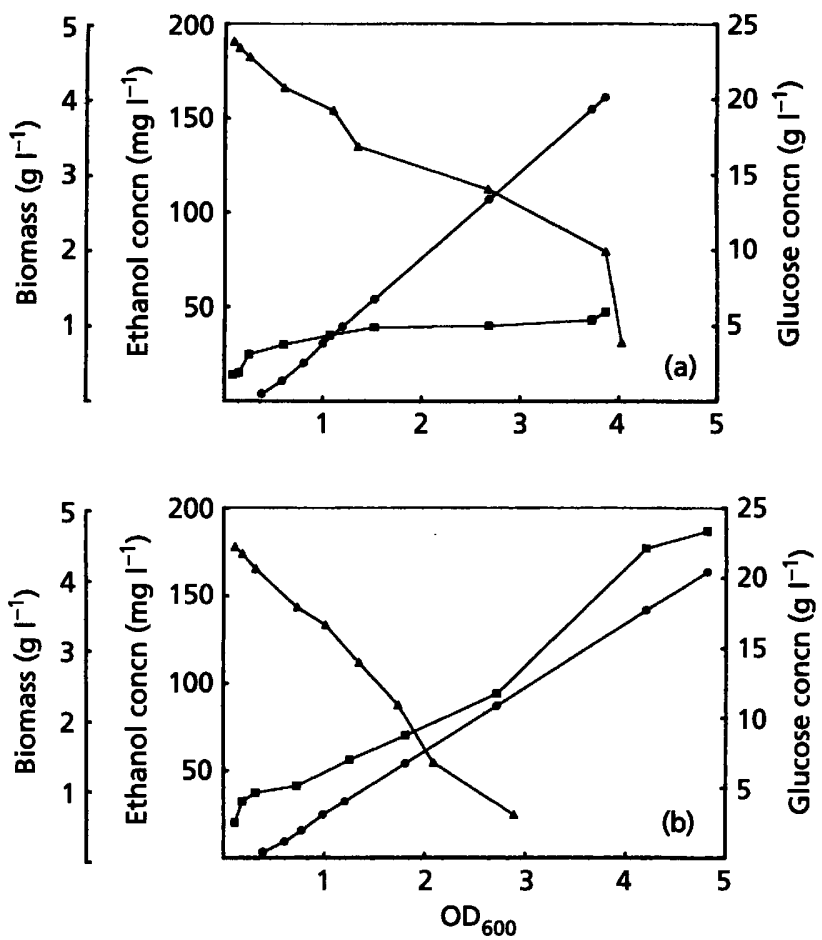

Fig. 6. Biomass (O), glucose consumption $(\boldsymbol{\Delta})$ and ethanol production ( $\square$ ) by (a) wild-type $K$. marxianus cells and (b) gap1 mutant cells.

yeast as has been reported by Veenhuis et al. (1978); Wright et al. (1988); Binder et al. (1991); Simon et al. (1992); and Vergères et al. (1993).

The correlation between the expression of the GAP1 gene and the subsequent presence of the protein in the cell wall with the flocculation behaviour of the $K$. marxianus strain is clear as the mutant cells were no longer able to flocculate in the presence of calcium as occurs with the wild-type. Additionally, the mutant was sensitive to calcofluor white (Fig. 7a, b), which indicates that the structure of the cell wall is affected (Ram et al., 1994).

Besides the loss of flocculation, the disruption of GAP1 led to other changes such as those in growth and temperature tolerance. When gap1 cells were growing at $26^{\circ} \mathrm{C}$ they exhibited a more prolonged exponential phase and cell density reached a higher value (Fig. 5a); however, due to a change in cell size, the biomass yield remained the same (Fig. 6). With regard to the fermentation yield, when glucose and ethanol were estimated, it was found that the mutant cells were able to produce more ethanol. The shift to a more fermentative metabolism can be related to the decrease in GAPDH activity (Table 1). In fact, since GAP1 contributes to GAPDH activity, its disruption probably affects the rate of production of energy and reducing equivalents by the glycolytic pathway. As a consequence, the cells change to a more fermentative metabolism, which is a less 

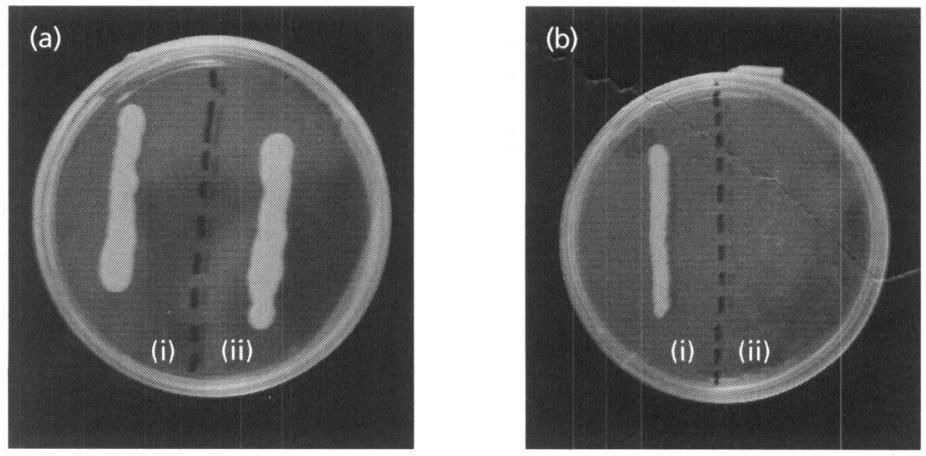

Fig. 7. Wild-type (a) and gap1 mutant (b) $K$. marxianus cells grown on YPD agar (i) and YPD agar supplemented with calcofluor white (ii).

Table 1. Assay of GAPDH activity in $K$. marxianus strains using different carbon sources

\begin{tabular}{|lcc|}
\hline Strain & Growth medium & $\begin{array}{c}\text { GAPDH activity } \\
{\left[\mathbf{m i n}^{-1}(\mathbf{m g} \text { total protein })^{-1}\right]}\end{array}$ \\
\hline Wild-type & $2 \%$ glucose & $2 \cdot 0$ \\
gap1 mutant & $2 \%$ glucose & $1 \cdot 5$ \\
Wild-type & $3 \%$ ethanol & $1 \cdot 4$ \\
gap1 mutant & $3 \%$ ethanol & $0 \cdot 7$ \\
\hline
\end{tabular}

efficient but quicker way of obtaining energy for cell survival. In the wild-type, the contribution of $\mathrm{p} 37$ to total GAPDH activity was not negligible as it represented $25 \%$ when glucose was utilized as carbon source. When ethanol was used as the carbon source, it contributed $50 \%$ of total activity. This is in agreement with a previous finding that GAP1 expression is increased when cells are growing in ethanol, the expression of GAP2 being very reduced (Fernandes et al., 1995). In the presence of ethanol, this high GAPDH activity cannot be related to the rate of glycolysis, suggesting an additional role for the protein. In fact, data from different cell systems revealed that it has many different cellular localizations and functions. Recent evidence revealed the presence of GAPDH in the surface of Candida albicans (Gil-Navarro et al., 1997) and previously GAPDH has been found to be associated with the red blood cell membrane (Allen et al., 1987). Its mutation alters endocytosis in CHO cells (Robbins et al., 1995); it is involved in multiple binding activity in group A streptococci (Pancholi \& Fischetti, 1992); in bundling and unbundling of miocrotubules (Huitorel \& Pantolini, 1985); protein kinase activity in the phosphorylation of transverse-tubule proteins (Kawamoto \& Caswell, 1986); ssDNA binding activity (Perucho et al., 1977); tRNA binding activity (Singh \& Green, 1993) and uracil DNA glycosylase activity (Meyer-Siegler et al., 1991).

K. marxianus is quite tolerant of temperatures up to $42{ }^{\circ} \mathrm{C}$ (Sá Correia \& van Uden, 1982; Vivier et al., 1993), and the mutant strain grows well at $40{ }^{\circ} \mathrm{C}$ provided that calcium is present. Indeed, the gap 1 mutant cannot grow at $40^{\circ} \mathrm{C}$ in the absence of calcium and cell death is observed (Fig. 5c). The addition of calcium after a $24 \mathrm{~h}$ period at $40^{\circ} \mathrm{C}$ cannot rescue cell growth. A relationship between thermosensitivity and the ability of the cells to flocculate was also reported for S. cerevisiae, which becomes more thermoresistant when the cells are able to flocculate (Bossier et al., 1997). At present we cannot put forward any mechanisms that could account for the effect of calcium on thermotolerance; however, it is plausible to envisage that, by interacting with the negative charges on the surface, calcium can stabilize the structure of cell walls affected by the absence of p37, allowing the cells to avoid cell disruption and survive.

The present work provides evidence that $\mathrm{p} 37$ plays a key role in the architecture of the cell wall in conditions where flocculation occurs as there is a net correlation between the presence of $\mathrm{p} 37$ with the ability of cells to flocculate, and in thermotolerance as mutant cells are no longer able to grow at a more elevated temperature. Flocculation of $\mathrm{K}$. marxianus is induced by a temperature upshift from $26^{\circ} \mathrm{C}$ to $40^{\circ} \mathrm{C}$ (Fernandes et al., 1993); therefore p37 is probably related to a cell protection mechanism against thermal stress, which leads to flocculation. In fact, flocculation has already been described as a defensive mechanism developed by cells to survive under stress (Moradas-Ferreira et al., 1994).

\section{ACKNOWLEDGEMENTS}

This work was supported by grant PRAXIS 2/2.1/ Bio/1052/95 and R. F. Moreira thanks PRAXIS for grant $\mathrm{BD} / 4551 / 94$. The neomycin resistance gene was kindly provided by Professor Rudi Planta (Vrije University, Amsterdam, The Netherlands). We thank Professor Cecília Leão (University of Minho, Portugal) for helpful suggestions. 


\section{REFERENCES}

Allen, R. W., Trach, K. A. \& Hoch, J. A. (1987). Identification of the $37 \mathrm{kDa}$ protein displaying a variable interaction with the erythroid cell membrane as GAPDH. J Biol Chem 262, 649-653.

Alloush, H. M., López-Ribot, J. L., Masten, B. J. \& Chaffin, W. L. (1997). 3-Phosphoglycerate kinase: a glycolytic enzyme protein present in the cell wall of Candica albicans. Microbiology 143, 321-330.

Ausubel, F., Brent, R., Kingston, R., Moore, D., Seidman, J. G., Smith, J. \& Struhl, K. (1987). Current Protocols in Molecular Biology. New York: Wiley Interscience.

Binder, M., Schanz, M. \& Hartig, A. (1991). Vector-mediated overexpression of catalase A in the yeast Saccharomyces cerevisiae induces inclusion body formation. Eur J Cell Biol 54, 305-312.

Binder, M., Hartig, A. \& Sata, T. (1996). Immunogold labelling of yeast cells: an efficient tool for the study of protein targeting and morphological alteration due to overexpression and inactivation of genes. Histochem Cell Biol 106, 115-130.

Bossier, P., Goethals, P. \& Rodrigues-Pousada, C. (1997). Constitutive flocculation in Saccharomyces cerevisiae through overexpression of the GTS1 gene, coding for a 'Glo'-type Zn-fingercontaining protein. Yeast 13, 717-725.

Fernandes, P. A., Keen, J. N., Findlay, J. B. C. \& Moradas-Ferreira, P. (1992). A protein homologous to glyceraldehyde-3-phosphate dehydrogenase is induced in the cell wall of a flocculent Kluyveromyces marxianus. Biochim Biopbys Acta 1159, 67-73.

Fernandes, P. A., Sousa, M. \& Moradas-Ferreira, P. (1993). Flocculation of Kluyveromyces marxianus is induced by a temperature upshift. Yeast 9, 859-866.

Fernandes, P. A., Sena Esteves, M. \& Moradas-Ferreira, P. (1995). Characterization of the glyceraldehyde-phosphate dehydrogenase gene family from Kluyveromyces marxianus - Polymerase Chain Reaction-single-strand conformation polymorphism as a tool for the study of multigenic families. Yeast 11, 725-733.

Gil-Navarro, I., Gil, M. L., Casanova, M., O'Connor, J. E., Martinez, J. P. \& Gozalbo, D. (1997). The glycolytic enzyme glyceraldehyde3-phosphate dehydrogenase of Candida albicans is a surface antigen. $J$ Bacteriol 179, 4992-4999.

Holland, M. J. \& Westhead, E. W. (1973). Chemical reactivity at the catalytic sites of aspartic-semialdehyde dehydrogenase and glyceraldehyde-3-phosphate dehydrogenase. Biochemistry 12, 2276-2281.

Holmberg, S. (1978). Isolation and characterization of a polypeptide absent from non-flocculent mutants of Saccharomyces cerevisiae. Carlsberg Res Commun 43, 401-413.

Huitorel, P. \& Pantolini, D. (1985). Bundling of microtubules by glyceraldehyde-3-phosphate dehydrogenase and its modulation by ATP. Eur J Biochem 150, 265-269.

Kawamoto, R. M. \& Caswell, A. H. (1986). Autophosphorylation of glyceraldehyde-3-phosphate dehydrogenase and phosphorylation of protein from skeletal muscle microsomes. Biochemistry 25, 656-661.

Meyer-Siegler, K., Mauro, D. J., Seel, G., Weirzer, J., Deriel, J. K. \& Sirover, M. A. (1991). A human nuclear uracil DNA glycosylase is the $37 \mathrm{kDa}$ subunit of glyceraldehyde-3-phosphate dehydrogenase. Proc Natl Acad Sci USA 88, 8460-8464.

Miki, B. L. A., Poon, N. H., James, A. P. \& Seligy, V. L. (1982). Possible mechanism for flocculation interactions governed by gene FLOI in Saccharomyces cerevisiae. J Bacteriol 150, 878-889.

Moradas-Ferreira, P., Fernandes, P. A. \& Costa, M. J. (1994). Yeast flocculation - the role of cell wall proteins. Colloids Surf B Biointerf 2, 159-164.

Nishihara, H., Toraya, T. \& Fukui, S. (1976). Induction of flocforming ability in brewer's yeast. J Ferment Technol 54, 356-360.

Nishihara, H., Toraya, T. \& Fukui, S. (1977). Effect of chemical modification on cell surface components of a brewer's yeast on the floc forming ability. Arch Microbiol 115, 19-23.

Pancholi, V. \& Fischetti, V. A. (1992). A major surface protein on group A Steptococci is a glyceraldehyde-3-phosphate dehydrogenase with a multiple binding activity. J Exp Med 176, 415-423.

Perucho, M., Salas, J. \& Salas, M. L. (1977). Identification of the mammalian DNA-binding protein P8 as a glyceraldehyde-3phosphate dehydrogenase. Eur J Biochem 81, 557-560.

Ram, A. F. J., Wolters, A., Ten Hoopen, R. \& Klis, F. M. (1994). A new approach for isolating cell wall mutants in Saccharomyces cerevisiae by screening for hypersensitivity to calcofluor white. Yeast 10, 1019-1030.

Robbins, A. R., Ward, R. D. \& Oliver, C. (1995). A mutation in glyceraldehyde 3-phosphate dehydrogenase alters endocytosis in CHO Cells. J Cell Biol 130, 1093-1104.

Rothstein, R. J. (1983). One-step gene disruption in yeast. Methods Enzymol 101, 202-210.

Russell, I., Stewart, G. G., Reader, H. P., Johnston, J. R. \& Martin, P. A. (1980). Revised nomenclature of genes that control flocculation. J Inst Brew 86, 120-121.

Sá Correia, I. \& van Uden, N. (1982). Effects of ethanol on thermal death and on the maximum temperature for growth of the yeast Kluyveromyces fragilis. Biotechnol Lett 4, 805-808.

Saito, K., Sato, S., Shimoi, H., lefugi, H. \& Tadenuma, M. (1990). Flocculation mechanism of Hansenula anomala. Agric Biol Chem 54, 1425-1432.

Sambrook, J., Fritsch, E. F. \& Maniatis, T. (1989). Molecular Cloning: a Laboratory Manual, 2nd edn. Cold Spring Harbor, NY: Cold Spring Harbor Laboratory.

Simon, M., Binder, M., Adam, G., Hartig, A. \& Ruis, H. (1992). Control of peroxisome proliferation in Saccharomyces cerevisiae by ADR1, SNF1, and SNF4. Yeast 8, 303-309.

Singh, R. \& Green, M. R. (1993). Sequence-specific binding of transfer RNA by glyceraldehyde-3-phosphate dehydrogenase. Science 259, 365-368.

Stewart, G. G. \& Russell, I. (1977). The identification, characterization, and mapping of a gene for flocculation in Saccharomyces sp. Can J Microbiol 23, 441-447.

Stewart, G. G., Garrison, I., Goring, T. G., Meleg, M., Pipats, P. \& Russell, I. (1976). Biochemical and genetic studies on yeast flocculation. Kem Kemi 3, 465-479.

Stratford, M. \& Carter, A. (1993). Yeast flocculation: lectin synthesis and activation. Yeast 9, 371-378.

Straver, M. H., Smit, G. \& Kijne, J. W. (1993). Induced cell surface hydrophobicity influences flocculation of brewer's yeast in flocculation assay. Colloids Surf B Biointerf 2, 173-180.

Teunissen, A. W. R. H., Van den Berg, J. A. \& Steensma, H. Y. (1993). Physical localization of the gene Flo1 on a chromosome I of Saccharomyces cerevisiae. Yeast 9, 1-10.

Veenhuis, M., van Dijken, J. P., Pilon, S. A. F. \& Harder, W. (1978). Development of crystaline peroxisomes in methanol-grown cells of the yeast Hansenula polymorpha and its relation to environmental conditions. Arch Microbiol 117, 153-163.

Vergères, G., Yen, T. S. B., Aggeler, J., Lausier, J. \& Waskell, L. (1993). A model system for studying membrane biogenesis: overexpression of cytochrome $b_{5}$ in yeast results in marked 
proliferation of the intracellular membrane. J Cell Sci 106, 249-259.

Vezinhet, F., Blondin, B. \& Barre, P. (1991). Mapping of the Flo5 gene of Saccharomyces cerevisiae by transfer of a chromosome during cytoduction. Biotechnol Lett 13, 47-52.

Vivier, D., Ratomahenina, R., Moulin, G. \& Galzy, P. (1993). Study of physicochemical factors limiting the growth of Kluyveromyces marxianus. J Indust Microbiol 11, 157-161.
Wright, R., Bassom, M., D'ari, L. \& Rine, J. (1988). Increased amounts of HGM-CoA reductase induce "Karmellae": a proliferation of stacked membrane pairs surrounding the yeast nucleus. J Cell Biol 107, 101-114.

Received 4 August 1997; revised 3 November 1997; accepted 7 November 1997. 